\title{
LEGAL ANALYSIS OF ARTICLE 7 OF THE CONVENTION ON THE RIGHTS OF PERSONS WITH DISABILITIES: CHILDREN WITH DISABILITIES
}

\author{
IGNACIO CAMPOY CERVERA ${ }^{1}$
}

\begin{abstract}
The aim of this article is to carry out an in-depth analysis of Article 7, "Children with disabilities", of the Convention on the Rights of Persons with Disabilities. First of all it is explained how the Article 7 is the result of two different models of human rights: the "renewed" protectionism in relation with the children's rights and the social model in relation with the rights of persons with disabilities. After, it is explained how was the development of the creation of Article 7 within the Ad Hoc Committee which was created for the elaboration of the Convention. In an extensive section it is analysed the wording of Article 7, particularly taking account of the General Comments of the Committee on the Rights of Persons with Disabilities and the Committee on the Rights of the Child. Finally, the analysis of the meaning and scope of Article 7 is completed, taking into account other articles of the Convention and the jurisprudence of the European Court of Human Rights.
\end{abstract}

Keywords: Children Rights, Children with Disabilities Rights, Human Rights, Convention on the Rights of Persons with Disabilities, European Court of Human Rights.

Summary: I. INTRODUCTION. II. ARTICLE 7 IN THE LIGHT OF THE "RENEWED" PROTECTIONISM AND THE SOCIAL MODEL. III BACKGROUND AND TRAVAUX PRÉPARATOIRES. IV. ANALYSIS OF THE WORDING OF ARTICLE 7 IV.1. Paragraph 1. IV.2. Paragraph 2. IV.3. Paragraph 3. V. The Inter-Relationship BETWEEN ARTICLE 7 AND OTHER CRPD ARTICLES. VI. THE INTERPRETATION OF ARTICLE 7 IN THE EUROPEAN COURT OF HUMAN RIGHTS. VII. CONCLUDING REMARKS.

\section{INTRODUCTION}

Article 7 of the Convention on the Rights of Persons with Disabilities (hereinafter the CRPD), establishes:

1. States Parties shall take all necessary measures to ensure the full enjoyment by children with disabilities of all human rights and fundamental freedoms on an equal basis with other children.

2. In all actions concerning children with disabilities, the best interests of the child shall be a primary consideration.

3. States Parties shall ensure that children with disabilities have the right to express their views freely on all matters affecting them, their views being given due weight in accordance with their age and maturity, on an equal basis with other children, and to be provided with disability and age-appropriate assistance to realize that right.

Article 7 CRPD has to be considered the most important Article in relation with the rights of children with disabilities in the human rights system, so is necessary to

\footnotetext{
${ }^{1}$ Universidad Carlos III de Madrid, Spain (ignacio.campoy@uc3m.es).
} 
have a good understanding of its meaning. This article has the aim to be a contribution for the correctly understanding of Article 7 CRPD.

To achieve this best understanding, in the second Section we will consider how Article 7 is the result of two different models of human rights that have been developed in the historical evolution of human rights: the "renewed" protectionism in relation with the children's rights and the social model in relation with the rights of persons with disabilities. In the third Section, we will address the background and travaux préparatoires that were carried out within the Ad Hoc Committee which was created by the General Assembly of the United Nations (in its resolution 56/1968 of 19 December 2001) for the elaboration of a comprehensive and integral international Convention to promote and protect the rights and dignity of persons with disabilities, until the CRPD was finally approved. This analysis will allow us to identify the different positions that existed on to incorporate or not an article dedicated to children with disabilities, as well as with regard to its content. In the fourth Section, we will analyse the wording of article 7, paragraph by paragraph, particularly taking account of the General Comments of the Committee on the Rights of Persons with Disabilities and the Committee on the Rights of the Child, with the aim to have the best possible understanding of its meaning within the human rights model. Finally, we will dedicate the last two Sections to complete the understanding of the meaning and scope of Article 7 dealing with its connection with other Articles of the CRPD (Section fifth) and its interpretation and application by the European Court of Human Rights (Section sixth).

\section{ARTICLE 7 IN THE LIGHT OF THE “RENEWED” PROTECTIONISM AND THE} SOCIAL MODEL

Article 7 CRPD ought to be understood as the result of the application of the principles underlying the current paradigm of children's rights to children with disabilities, in accordance with the modifications required by the social model of disability.

The current paradigm of children's rights was embodied in the 1989 United Nations Convention on the Rights of the Child (hereinafter the CRC) ${ }^{2}$. As the new paradigm it was, its roots and implications have been very different and numerous. However, one could still claim that the fundamental change it resulted in -with a terminology that was quite successful in specialized literature- was to stop considering the child as a legal "object" of protection and start considering him/her as a legal "subject" instead. In other terms, it led to cease regarding the child as an admittedly valuable person, who therefore deserves the protection he/she ought to be guaranteed by law, but who is nonetheless characterized by being a defenceless, imperfect and incapable person, and therefore disqualified, for the entire duration of his/her childhood, from exercising his/her rights. Rather, it began to be considered that, although the child continues to be characterized by his special defencelessness and incapacity in essential aspects, thus justifying that emphasis still be placed on the special protection he/she must be provided, he/she is also a person who should be able to take, to the degree

\footnotetext{
${ }^{2}$ In other works we have referred to the paradigm shift that occurred with the CRC, moving from what could be considered a "traditional" protectionist model (which began developing in the seventeenth century) to a model that could be understood as "renewed" protectionism (which was already evident in the 1960s and 1970s, especially in Anglo-Saxon societies). An in-depth study of both models can be found in Chapter III of (Campoy Cervera, 2006, 421-600).
} 
possible, the relevant decisions for the direction of his/her life. Thus, calling to mind the evolution of his/her capacities during the different vital stages of his/her development, the child's opinion ought to be taken into account in all decision-making affecting him/her, even if it still has to be assessed, by qualified third parties, in accordance with his/her age and maturity.

It therefore ensues, on the basis of this new paradigm of "renewed" protectionism, that two essential ideas regarding the recognition and protection of children's rights must be considered: firstly, that through the law, certain basic aspects of the life of the child must be protected. Those aspects, deemed necessary for his/her proper development as a person, can be considered to constitute, as per Article 3.1 of the CRC, "the best interests of the child", which is the principle that had been sustained by "traditional" protectionism. Secondly, that the child must participate, in accordance with his/her age and level of maturity, in the decision-making that is carried out with regard to those matters that affect him/her, as per Article 12 of the CRC, which is the new principle that would lead to the change promoted by "renewed” protectionism.

Thus are established the two fundamental pillars on which the theoretical construction and legitimation of the current model of recognition and protection of children's rights is based. As already stated, the model was endorsed by the CRC, and subsequently reflected in the last two paragraphs of Article 7 of the CRPD: protecting the best interests of the child and ensuring his/her participation in the decision-making bound to affect him/her ${ }^{3}$.

The Committee on the Rights of the Child itself has identified Articles 2, 3.1, 6 and 12 of the CRC as those that set out the general principles of the Convention. This adds two supplementary articles as general principles. The general dimension of Article 6 of the CRC is clear: it recognizes the intrinsic right of every child to life, and establishes that States Parties must ensure, to the maximum extent possible, his/her survival and development. This clearly provides the necessary basis for understanding that children are human beings, and that they therefore possess a dignified life that ought to be protected. However, we believe it is Article 2, which establishes the right to non-discrimination as a basic principle, that deserves special attention here: "States Parties shall respect and ensure the rights set forth in the present Convention to each child within their jurisdiction without discrimination of any kind, irrespective of the child's or his or her parent's or legal guardian's race, colour, sex, language, religion, political or other opinion, national, ethnic or social origin, property, disability, birth or

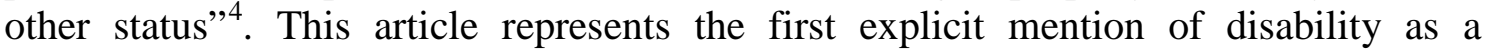
prohibited ground for discrimination, thus acknowledging that disabled children, like other children, are owed the obligation established by that article of the States Parties "to ensure that all children within their jurisdiction enjoy all the rights enshrined in the Convention” 5 .

\footnotetext{
${ }^{3}$ Along these lines, Jorge Cardona considers these two principles/rights as "revolutionary" in relation to the previous situation and as the "central axis of the paradigm shift" (Cardona Llorens, 2014, 23). We have established the relationship between these principles, advocating an interpretation of them that allows for the full incorporation of the rights of children, with or without disability, into the human rights model, in (Campoy Cervera, 2017b).

${ }^{4}$ The second paragraph of Article 2 of the CRC extends the prohibition of discrimination from which children may suffer because of their parents, guardians or relatives.

${ }^{5}$ United Nations Committee on the Rights of the Child "General Comment No 9 on the rights of children with disabilities” (27 February 2007) CRC/C/GC/9 (hereafter CRC General Comment No 9), para. 8.
} 
Hence, Article 2 is of special importance because it most directly establishes the connection between the rights of children with disabilities and the social model of disability $^{6}$. In this regard, Rafael de Asís has identified as one of the four postulates that serve to generically describe the social model, that "the normative policy in the field of the rights of persons with disabilities must be inserted in the framework of equality and non-discrimination and, within that framework, in the field of the generalization of rights"7. It is along those lines that it was previously pointed out that Article 7 of the CRPD implies the extension of the current paradigm of the rights of children to children with disabilities according to the modification imposed by the social model of disability. Indeed, there is an explicit connection between Article 2 of the CRC and the first paragraph of Article 7 of the CRPD, as well as between the two basic principles of Articles 3.1 and 12.1 of the CRC, and their recognition in paragraphs 2 and 3 of Article 7 of the CRPD.

\section{BACKGROUND AND TRAVAUX PRÉPARATOIRES}

The first reference to children with disabilities can already be found in the Working Paper presented by Mexico at the first Working Session (held from 29 July to 2 August 2002) of the Ad Hoc Committee which was created by the General Assembly of the United Nations (in its resolution 56/1968 of 19 December 2001) for the elaboration of a comprehensive and integral international Convention to promote and protect the rights and dignity of persons with disabilities. However, the reference was made solely in what was then proposed as Article 13, which addressed to "promote access for persons with disabilities to the medical and rehabilitation services they require so as to guarantee their right to health and to foster their autonomy and independent lives". The object was to point out that it was one of the groups that should particularly be guaranteed "receive quality medical attention within state healthcare systems ${ }^{\text {p }}$.

In the Final Statement of 6 May 2003 of the Disability African Regional Consultative Conference, it was already stated that children with disabilities (along with other groups in particularly vulnerable situations, such as women and the elderly) face double oppression, and therefore, that particular "oppression has to be acknowledged and focused programmes developed to address it"9 . Furthermore, among the proposals compiled in the Seminar of Quito for the elaboration of the Convention there was a call for the inclusion of a series of themes among the articles of the Convention that would form a basic thematic structure; hence the "Specific rights of vulnerable groups (children, the girl child, adolescents, women, ethnic minorities, older persons, among

\footnotetext{
${ }^{6}$ This by no means diminishes the relevance of Article 23 of the CRC, which explicitly refers to the rights of children with disabilities and was key in the transition toward the social model. In this regard, the Committee on the Rights of the Child noted in its General Comment No. 9: "Paragraph 1 of article 23 should be considered as the leading principle for the implementation of the Convention with respect to children with disabilities (...) The core message of this paragraph is that children with disabilities should be included in the society..." (CRC General Comment No 9, para. 11).

${ }^{7}$ The other three postulates that the author identifies are: "The correct approach to address disability from a normative point of view is that of human rights"; "Disability is, above all, a situation in which people are or can be found in and not an individual trait that characterizes them"; and "disability has, in most cases, a social origin, so that measures aimed at satisfying the rights of persons with disabilities must have as their main target the society at large” (De Asís Roig, 2013, 16-17).

${ }^{8}$ http://www.un.org/esa/socdev/enable/rights/adhocmeetaac265w1e.htm.

9 http://www.un.org/esa/socdev/enable/rights/a_ac265_2003_crp11.htm.
} 
others)" ${ }^{10}$. In this manner, it was in the Bangkok Recommendations, which were made by the Ad Hoc Committee in its Second Session, from16 to 27 June 2003, that it was stated that the Convention should "stress that the situation of all disability groups and the diverse conditions related to gender, race, colour, age, ethnicity and other considerations must be taken into account, and recognize the impact of dual disadvantage and multiple discrimination faced by individuals such as, women, children or indigenous people with disabilities"11.

At any rate, the first time a specific article was dedicated to children with disabilities -Article 16- was in the Draft that was prepared by the Working Group established by the Ad Hoc Committee in its 14th meeting, on 27 June 2003, and which conformed the basis for the negotiation among Member States and observers ${ }^{12}$. Indeed, although other articles in the Draft also dealt with children with disabilities (for example, Article 17, which addressed education), this integral dedication of an article to children with disabilities is fundamental. Article 16 of the Draft basically reproduced the provisions of articles 2 and 23 of the CRC, but, as noted in a footnote, "duplicating Article 23 in this context, therefore, may not adequately deal with the issues faced by children with disabilities. The Ad Hoc Committee may wish to revisit this draft Article so that it instead covers issues that affect children with disabilities, but which have not been dealt with elsewhere in the Convention. Examples could include the vulnerability of children with disabilities to sexual abuse and exploitation, of refugee children with disabilities, and of orphan children with disabilities"13.

As a result, in the Report of the Third Session, from 24 May to 4 June 2004, Article 16 on the rights of children can be found in the Draft of the Convention. All the same, the first disagreements on the appropriateness of a specific article on children with disabilities were already made explicit at this time. Representatives from different countries (such as Ireland, on behalf of the EU, New Zealand or Israel), in discussing the article on 28 May 2004, expressed their doubts and/or reluctance regarding the convenience of an article on children with disabilities. Their understanding was that it was not necessary, or could even diminish the strength of the rights that had already been recognized them in the CRC. In a similar vein, the representative of Liechtenstein, while acknowledging the appropriateness of the article, pointed out that it "could be kept concise by referring to all the rights of the CRC, especially Article 23". Nonetheless, during the debate that day, all the NGOs present expressed themselves strongly in favour of a specific article on the rights of children with disabilities ${ }^{14}$.

In any case, it is also interesting to take note of the different proposals on the final text to be incorporated into the Working Group Draft: at times, because they

\footnotetext{
${ }^{10}$ http://www.un.org/esa/socdev/enable/rights/a_ac265_2003_crp13.htm.

${ }^{11}$ http://www.un.org/esa/socdev/enable/rights/a_ac265_2003_crp10.htm.

${ }_{12}$ The demand for dedicating a specific article to the rights of children with disabilities can also be seen in the Chair's Draft Elements of a Comprehensive and Integral International Convention on Protection and Promotion of the Rights and Dignity of Persons with Disabilities, of December 2003. As it is said in its Introduction: "The Draft is intended as a contribution to the deliberations of the Working Group in its work of elaborating a draft convention to be presented to the Ad Hoc Committee”; and it dedicates its Article 18 to the "Rights of children with disabilities", with a content that, in fact, is included in the more extend content of Article 16 which is analyzed in the main text. The Draft is available at http://www.un.org/esa/socdev/enable/rights/wgcontrib-chair1.htm.

${ }^{13}$ http://www.un.org/esa/socdev/enable/rights/ahcwgreporta16.htm.

14 http://www.un.org/esa/socdev/enable/rights/ahc3sum16.htm.
} 
address different issues that are particularly relevant for children with disabilities (as would be the prohibition of the sterilization of children and young people with disabilities $)^{15}$; but most importantly, taking into account the final wording of the Convention, it is the incorporation of two paragraphs upon the proposals of Canada and Uganda respectively, that acquires particular relevance. The former addressed the right of the children to participate in all matters affecting them: "States Parties recognize the evolving capacities of children with disabilities in the exercise of their rights, and the right of children with disabilities to express their views freely on all matters affecting them, their views being given due weight in accordance with the child's age and maturity"; the second stated, with regard to the best interests of the child, that "States Parties shall ensure that in all decisions concerning children with disabilities whether undertaken by public or private social welfare institutions, courts of law, administrative authorities or legislative bodies, the best interests of the child shall be of primary consideration" 16 .

In the Report of the Sixth Session of the Ad Hoc Committee, it was concluded, in Paragraph 27, that "there was general agreement in the Committee that some specific references to children with disabilities were needed in the draft convention. There was also general agreement that draft Article 16 did not add much substance to what was already contained in Article 23 of the Convention on the Rights of the Child" ${ }^{17}$. As a result, three possible options were proposed with regard to the inclusion of children with disabilities in the Draft Convention: the inclusion of a separate article on children, "a reference in the preamble with a general statement in a draft article of horizontal application (such as draft articles 2, 4, or 25), or mainstreaming references in relevant thematic draft articles” ${ }^{\prime 18}$. Faced with these possibilities, the International Disability Caucus clearly defended the need to establish a specific article for children with disabilities, because, ultimately, what was sought with it was "to ensure that the rights embodied both within the Convention on the Rights of the Child and the present

\footnotetext{
${ }^{15}$ Representatives from different countries (New Zealand, India or Canada, among others) also pointed to the incorporation of other possible paragraphs that addressed specific aspects which could affect the lives of children with disabilities, such as early detection , alternative family care, or, as New Zealand pointed out, "by addressing the 'extra vulnerabilities' of children with disabilities to rejection, abandonment”.

16 http://www.un.org/esa/socdev/enable/rights/ahc3reporte.htm. Along the same lines, the National Human Rights Institutions advocated for the incorporation of a paragraph dedicated to the best interests of the child and another to the right to participation

(http://www.un.org/esa/socdev/enable/rights/ahc3sum16.htm).

17 Report of the Ad Hoc Committee on a Comprehensive and Integral International Convention on the Protection and Promotion of the Rights and Dignity of Persons with Disabilities on its sixth session, para. (http://www.un.org/esa/socdev/enable/rights/ahc6reporte.htm (A/60/266, Annex II, 17 August 2005, para. 27 (http://www.un.org/esa/socdev/enable/rights/ahc6reporte.htm).

18 Ibid, para. 28. However, in the Report of the Facilitator it is stated that the "plenary on 2nd August 2005 generated debate that identified 5 approaches to ensuring that concerns on the rights of children with disabilities are adequately addressed". It is added to the three referred to in the main text, the possibility to "have a combination of mainstreaming of children's issues in all relevant articles and also have an article on children to cover the issues that are unique to children and cannot be included in any other articles in the draft convention"; or "to refer to children in the general articles as in (1) above and then specifically require, in the monitoring article, that State Parties show how they have implemented all the provisions of the this convention with respect to children with disabilities; the article monitoring should also include an expert on the treaty body on matters relating children with disability" (http://www.un.org/esa/socdev/enable/rights/ahc6facilitator.htm).
} 
Convention are fully respected for children with disabilities. Without its inclusion, the risk is that they are marginalised in both" ${ }^{\prime 19}$.

In any case, it is relevant to note that some of the key issues that were resolved in the meetings that took place between 4 and 11 August 2005 addressed concrete (but extremely important) issues for children with disabilities (such as protection from sterilization), but also the fundamental foundations for the model of the rights of children with disabilities. This included equality between all children (with and without disabilities) in the recognition and protection of rights ("The need to include the principle of equality with other children in the application of all human rights and fundamental freedoms. This will complement and reinforce the application of the CRC with respect to children with disabilities" ${ }^{20}$ ), as well as the two essential principles: in first place, that of the best interests of the child ("The need to include the principle of "the best interest of the child" in all actions concerning children with disabilities under this convention" ${ }^{21}$ ), which is consistent with, but goes beyond, the idea that is necessary to protect the child due to his special vulnerability ${ }^{22}$ ("because of the vulnerability of children due to their age, lack of autonomy or legal capacity as adults, children are entitled to protection that will address their particular situations and ensure their right to development. It is important that this convention recognizes this and makes provisions specifically address the rights in this convention as they apply to children” ${ }^{23}$ ). In second place, that of the protection of the possibility that the child participate in the exercise of his rights due to the evolution of his capacities, which is in turn consistent with the principle of child participation in all decision-making affecting him/her ("States Parties shall ensure that children with disabilities enjoy a full and decent life, in conditions that ensure dignity, promote self-reliance and autonomy, and facilitate the child's active participation in the community”24).

In any case, the differences in the positions that were held on "whether there should be a separate article on children with disabilities, or whether the particular disadvantages and vulnerabilities of children with disabilities should be dealt with in a separate article or alternative approaches", resulted in the fact that in the Draft Comprehensive and Integral International Convention on the Protection and Promotion of the Rights and Dignity of Persons with Disabilities, submitted by the Chairman on the basis of discussion by the Ad Hoc Committee, the article on the rights of children (which was now Article 7 instead of Article 16) was left blank. In his Letter to all Members of the Committee, dated 7 October 2005, the Chairman justified this by stating that "the wording for Article 7 as found in the Working Group text did not

\footnotetext{
19 “Article 16, Children with disabilities. Prepared by the International Disability Caucus”, http://www.un.org/esa/socdev/enable/rights/ahc6contngos.htm.

${ }^{20}$ http://www.un.org/esa/socdev/enable/rights/ahc6facilitator.htm.

21 http://www.un.org/esa/socdev/enable/rights/ahc6facilitator.htm.

22 In this line, Andrea Broderick notes that on the travaux préparatoires: "The debate centred around two principal concerns. The first issue that arose at the negotiation sessions was whether it was in fact necessary to have a separate article on children with disabilities (...) The second, and related, issue that arose at the negotiation sessions was that if there was to be a specific article for children with disabilities, it must go far beyond and the content of international human rights law theretofore” (Broderick, 2017, 199).

${ }^{23}$ http://www.un.org/esa/socdev/enable/rights/ahc6facilitator.htm.

24 See in the contribution by Kenya http://www.un.org/esa/socdev/enable/rights/ahc6kenya.htm.
} 
receive a great deal of support, and it is clear that many delegations have problems with it. It did not receive general agreement as a good basis for our future work" ${ }^{25}$.

The discussion on the best strategy on how to be most effective in the recognition of children with disabilities was held in the sessions of 1 and 2 February $2016^{26}$. During these sessions, the Facilitator's text on women and children with disabilities were jointly discussed, and delegates maintained both the position of establishing a separate right for children with disabilities and integrating it into other articles of the Convention (although the NGOs that participated clearly opted for an article on the rights of children with disabilities). This led the Chair to conclude that "regarding the question of whether or not to include separate articles on women and children with disabilities, there was clear support for the twin-track approach. Many delegates favoured inclusion of separate articles, while others preferred to include the general provisions on women and children in Article 4 on General Obligations. The Chair noted that most of those who preferred the latter also expressed their flexibility on the matter. There was undoubtedly clear consensus on the need to somehow address the particular problems and vulnerabilities faced by these two groups of persons with disabilities, however there was still disagreement as to the best manner in which to do so. The Chair requested delegates to come to the August meeting with a flexible position and an open mind on this structural issue to facilitate quick resolution. He stressed that this issue is a matter of structure, not an issue of substance. For the moment, the Chair noted that the most appropriate solution would be to amend Articles 6 and 7 according to the discussions just held and then to bracket the language in the text issued for consideration at the Eighth Session” ${ }^{27}$.

However, with regard to the debate on the content of Article 7, the Chair concluded, at the end of that debate on 2 February 2006, that "Article 7(1) drew broad support. The emphasis on the need to broaden 7(2) to be consistent with the CRC's language "all actions concerning children" was generally supported. There was broad support for 7(3), however the discussion on 7(4) raised several issues. There was clear concern regarding the elements of this provision where there is overlap with 23(2 ter) and also with whether language similar to that in the CRC would be appropriate here. These issues should be revisited at the next meeting. The proposal to merge $7(1), 7(2)$ and 7(3) drew reasonable support provided that all elements are retained in the convention, and many delegates supported including some elements of 7(4) in that merger" ${ }^{28}$. In any case, on 3 February, the Committee adopted the Draft Report of the Convention in Annex II ("International Convention on the Rights of Persons with Disabilities. Working text”), which included a text for Article 7 (Children with disabilities) that was very similar to what would become the final version. Although the wording of the text was different, its division into three paragraphs, as well as the content of each of them, was very similar to the final version of Article $7^{29}$.

\footnotetext{
${ }^{25}$ http://www.un.org/esa/socdev/enable/rights/ahcchairletter7oct.htm, paras. 42 and 43.

${ }_{26}$ Those can be consulted at http://www.un.org/esa/socdev/enable/rights/ahc7sum01feb.htm and http://www.un.org/esa/socdev/enable/rights/ahc7sum02feb.htm respectively.

${ }^{27}$ http://www.un.org/esa/socdev/enable/rights/ahc7sum02feb.htm.

${ }^{28}$ http://www.un.org/esa/socdev/enable/rights/ahc7sum02feb.htm.

29 http://www.un.org/esa/socdev/enable/rights/ahc7report-e.htm, A/AC.265/2006/2. Thus modifying the proposals made by the facilitators, which included, in Article 7, a fourth paragraph that stated: "Every child with disability shall have the right to such measures of protection, assistance and care on the part of his or her family, society and the State as required by his or her minor status and are tailored to his or her individual circumstances. When a child with disability is deprived of his or her family environment or in
} 
Ultimately, it would be at the Eighth Session that the definitive version of Article 7 was adopted $^{30}$.

\section{ANALYSIS OF THE WORDING OF ARTICLE 7}

\section{IV.1. Paragraph 1}

The general meaning of the first paragraph of Article 7 responds to the need to incorporate the basic principles of the social model of disability into the specific field of children's rights. That is to say, it establishes that States must ensure that disability will never be an impediment for all children to enjoy, on an equal basis, their human rights and fundamental freedoms. This makes it fundamental to implement the principle/right of universal access.

In any case, we shall proceed to analyse this basic objective based on the two parts into which the paragraph can be divided.

"States Parties shall take all necessary measures to ensure the full enjoyment by children with disabilities".

As indicated in the "General Comment No 3 (2016) on women and girls with disabilities", of the Committee on the Rights of Persons with Disabilities (CRPD/C/GC/3), it must first be understood that these measures have to be taken in all possible areas: "measures can be of a legislative, educational, administrative, cultural, political, linguistic or other nature". Additionally, these must be understood as broadly as possible to achieve their objective, which, as have to be emphasized, is not only to ensure the enjoyment of all human rights and fundamental freedoms, but their "full enjoyment". Thus, it should be understood that the mandate is more demanding for States, which have to take "all necessary measures" to this aim, thus implying their obligation to respect, protect and fulfil the rights of all children with disabilities ${ }^{31}$. In this sense, it must be understood that the obligation "to respect" requires States Parties to refrain from interfering with the enjoyment of the rights of children with disabilities; the obligation "to protect" means that States Parties have to ensure that the rights of

whose own best interest cannot be allowed to remain in that environment such protection and assistance shall be provided by the State"; followed by the comment according to which "the text of this article may be located in Article 4 [dedicated to the General Obligations]" (http://www.un.org/esa/socdev/enable/rights/ahcstata7sevsfacilitator.htm).

${ }^{30}$ Thus, the only change in the text approved at its 22nd meeting, on 5 December 2006, with respect to the text adopted at its 20th meeting, on 25 August 2006, was the replacement of "best interest” by "best interests" in the second paragraph.

${ }^{31}$ In this sense, see in relation with women with disabilities, in the United Nations Committee on the Rights of Persons with Disabilities "General Comment No 3 on women and girls with disabilities" (25 November 2016) CRPD/C/GC/3, par. 24 (hereafter CRPD General Comment No 3). This is despite the fact that the expressions employed in Article 6 of the CRPD are "...shall take measures to ensure the full and equal enjoyment by them [women and girls with disabilities]...” and “...States Parties shall take all appropriate measures to ensure the full development, advancement and empowerment of women...”; whereas Article 7.1 states that "States Parties shall take all necessary measures to ensure the full enjoyment...”.

In the main text, we will employ, in relation to children with disabilities, the same wording that the Committee uses in paragraphs 25 to 27 of the CRPD General Comment No 3 to explain these obligations in relation to women with disabilities, because it makes sense to think that it has to be the same regarding children with disabilities. 
children with disabilities are not infringed upon by third parties, that includes "the duty to exercise due diligence by preventing violence or violations of human rights, protecting victims and witnesses from violations, investigating, prosecuting and punishing those responsible, including private actors, and providing access to redress and reparations where human rights violations occur"; and the obligation "to fulfil" imposes an ongoing and dynamic duty to adopt and apply the measures needed to secure the development, advancement and empowerment of children with disabilities. children".

"of all human rights and fundamental freedoms on an equal basis with other

This is the part of the text in which the application of the social model of disability to the rights of children can clearly be seen. Disability can by no means be considered any longer a reason to deny or limit the enjoyment of human rights and fundamental freedoms. This constitutes an obligation in accordance with the provisions of Article 5 of the CRPD and Articles 23 and 2 of the CRC: to ensure than the children with disabilities can enjoy their human rights on equal basis with other children is necessary to ensure the universal accessibility for all these rights. As stated in the General Comment No 2 of the Committee on the Rights of Persons with Disabilities, "when defining accessibility standards, States Parties have to take into account the diversity of persons with disabilities and ensure that accessibility is provided to persons of any gender and of all ages and types of disability"32.

In fact, we are faced here with what is surely the key element to fulfil the obligation for children with disabilities to exercise all their rights on an equal basis with other children, and that is the need to remove existing barriers and ensure universal access to children with disabilities. This requires that the design be applied to all and that they receive the necessary support and, where appropriate, reasonable adjustments in the exercise of their rights. This is a basic structure, which is transcendental if we want to make real the claim that children with disabilities can exercise their rights on an equal basis with others ${ }^{33}$.

The CRPD refers to the necessary supports and the reasonable adjustments in different articles (as in Articles 4, 9, 12, 16, 19, 20, 23, 24, 26, 29, 30 to the supports, and 2 -where a definition of reasonable adjustments is given-, 5, 13, 14, 24, 27 to the adjustments), although for children with disabilities the explicit references of Articles 13 and 23 are particularly relevant. The basic idea is that when, despite the universal design and the accessible measures that had been taken, it is shown that in reality children with disabilities still cannot enjoy their rights and freedoms on an equal basis with others because of the existence of barriers that affect them as a specific group or even individually, States Parties will need to ensure that such necessary supports are provided and ultimately the reasonable accommodation with which to deal with individual cases that have not been adequately addressed by the above measures, to ensure that all children, with or without disability, may enjoy or exercise their rights and freedoms on equal conditions.

\footnotetext{
${ }^{32}$ United Nations Committee on the Rights of Persons with Disabilities "General Comment No 2 Article 9: Acccesibility” (22 May 2014) CRPD/C/GC/2 (hereafter CRPD General Comment No 2) para. 29.

${ }^{33}$ It can be seen a developing of these ideas in relation with the recent legislative amendment in July 2015 of the Spanish system for the protection of children and adolescents, in (Campoy Cervera, 2016).
} 
A final consideration that needs to be made concerns the nature of the human rights and fundamental freedoms that are referred to in this paragraph. The answer stems from the confluence between the social model of disability and the "renewed" protectionism to which we referred to in the introductory section and that was also reflected in the section on the preparatory work. Based on the discussions on how to recognize the rights of children with disabilities in the Convention, it was clear that the idea was to make explicit as effectively as possible that children with disabilities, beyond certain specific rights (as could be the access to the comprehensive habilitation and rehabilitation services and programs referred to in Article 26 CRPD), had to have recognized the same rights and freedoms as the rest of the children and could enjoy them and exercise them on equal conditions. That is, disability could never be a source of discrimination for children. In this sense, Art. 23 CRC had been of historical importance, but it was necessary to emphasize that children with disabilities were, in the first instance, children, and that, therefore, States Parties should ensure that they could enjoy the same rights and freedoms as other children on equal basis ${ }^{34}$.

\section{IV.2. Paragraph 2}

As pointed out in the introductory section, the two general principles on which the CRC is based (apart from those of the right to non-discrimination -Art.2- and the right to life and development -Art. 6) are the primary consideration of the child's best interests -Art. 3.1- and the right of the child to be heard -Art. 12. This is precisely the manner in which it is necessary to understand the reiteration of these two general principles in Article 7 of the CRPD, which explicitly adopts the same system of recognition and protection of the rights of children for children with disabilities.

The drafting of the two general principles was confusing and in fact has given rise to different interpretations over the years ${ }^{35}$. However, in order to put an end to this situation of uncertainty, the Committee on the Rights of the Child drew up two General Comments regarding those two principles: CRC "General Comment No 14 on the right of the child to have his or her best interests taken as a primary consideration (art. 3, para. 1)" (29 May 2013) CRC/C/GC/14 and "General Comment No 12 the right of the child to be heard” (1 July 2009) CRC/C/GC/C12. Therefore, in clarifying the content of

\footnotetext{
${ }^{34}$ Needless to say, the progress that was made regarding children's rights was enormous. However, we cannot complete our analysis of this first paragraph of Article 7 without observing that this extension of the rights of children to the rights of children with disabilities also has a limitation derived from the application of the "renewed" protectionism model, but which, in our view, is not adjusted to the human rights model. Article 7 CRPD ensures that children with disabilities enjoy and exercise the same rights and freedoms as children without disabilities, but this implies that they also have the same limits to exercise them as the rest of the children. And those limits are unjustified according to the model of human rights. Children with disabilities, like the rest of the persons with disabilities, should have recognized, as established in Art. 12 CRPD, legal capacity on an equal basis with others in all aspects of life, and therefore, States Parties shall take appropriate measures to provide access by children with disabilities, as well as children without disabilities, to the support they may require in exercising their legal capacity. Some ideas on this matter can be consulted in (Campoy Cervera, 2017a, 17-31), and are further developed in (Campoy Cervera, 2017b).

35 Alston and Gilmour-Walsh already observed that the writers of the CRC failed to explain how to determine the best interests of the child and that the application of the principle would to a great extend depend on the interpretations made, in (Alston and Gilmour-Walsh, 1996, 10 and 15). A problem of vagueness that could also be ascribed to Article 12, as we can observe in relation with its drafting process in (Detrick, ed., 1992, 224-229).
} 
Article 7, it is necessary to follow the indications given in the General Comments by the Committee on the Rights of the Child.

\section{"In all actions concerning children with disabilities".}

In CRC General Comment No 14 it is analysed the phrase "In all actions concerning children" in paragraphs 17 to 24, and we know that the aim of the CRPD is to extend the same system of children's rights to children with disabilities, so the interpretation must be the same here.

The Committee on the Rights of the Child divides this phrase in three parts: "In all actions", "concerning" and "children" (for us children with disabilities). The principal aim of the analysis is to understand the phrase in its broadest meaning. In this line, it can be said that the idea is that we have to understand that the best interests of the child shall be a primary consideration in all the decisions, acts, conduct, proposals, services, procedures and other measures that are taken or are not taken (omissions) and directly or indirectly affect children with disabilities as a group or in general as well as if they have an effect on an individual child with any type of disability.

The phrase that has been cut in the article 7.2 CRPD in relation with article 3.1 CRC is referred to whom can take all those actions: "public or private social welfare institutions, courts of law, administrative authorities or legislative bodies" ${ }^{36}$. That phrase is analysed in the paragraphs 25 to 31 of General Comment No 14. Again the interpretation of the Committee on the Rights of the Child is very wide, extended to any public or private "institution whose work and decisions impact on children and the realization of their rights”; ““ccourts” refer to all judicial proceedings, in all instances whether staffed by professional judges or lay persons - and all relevant procedures concerning children, without restriction"; "the scope of decisions made by administrative authorities at all levels is very broad"; and the "adoption of any law or regulation as well as collective agreements"; even in paragraph 25 the Committee felt the obligation to remind that "Although parents are not explicitly mentioned in article 3 , paragraph 1, the best interests of the child "will be their basic concern" (art. 18, para. 1)". So on, it is necessary to understand that the actions whose are referred in Art. 7.1 CRPD could have been taken by any authority or institution and in any proceeding, formal or informal, where the best interests of the children with disabilities, as a group or attending an individual child with any type disability, can be affected.

“The best interests of the child".

The phrase "the best interests of the child" is analysed in paragraphs 29 and 30 of the CRC General Comment No 9, and in paragraphs 30 to 35 of the CRC General Comment No 14. Anyhow, in paragraphs 29 and 30 of the CRC General Comment No 9, it is little explained on what is the meaning of the best interests of the child, although it must be understood that the principle of the best interests of the child is applied to all children, with or without disabilities, without any discrimination. Nevertheless, for a better understanding of the meaning of the concept best interests of the child we have to attend to the CRC General Comment No 14.

\footnotetext{
${ }^{36}$ The complete text of Article 3.1 CRC is: "In all actions concerning children, whether undertaken by public or private social welfare institutions, courts of law, administrative authorities or legislative bodies, the best interests of the child shall be a primary consideration”.
} 
From the contents of paragraphs 30 to 35 of the General Comment No 14, it is clear that in all matters concerning a particular child or a particular group of children or children in general, it has to be clarified which is the best interests of the child / children in light of the specific circumstances of the particular child or the particular group and/or children in general; and then that best interests of the child /children shall be applied and taken into account to resolve any possible conflicts of rights.

In this line, it is said that the concept of the best interests of the child is complex, flexible and adaptable, and must be determined on a case-by-case basis. However, it is still undetermined what we can understand by the concept best interests of the child. In this sense, for a full understanding of the concept, it is better to attend to paragraphs 6 and 4 of the General Comment No 14.

In the paragraph 6 "The Committee underlines that the child's best interests is a threefold concept: (a) A substantive right (...) A fundamental, interpretative legal principle (...) A rule of procedure...”. Anyway, in my opinion, the best way to understand what the best interests of the child means, in the necessary context of the human rights model, is understanding its core and aim; and, in this sense, as it is established in paragraph 4: "The concept of the child's best interests is aimed at ensuring both the full and effective enjoyment of all the rights recognized in the Convention and the holistic development of the child". Understanding, as the Committee explain in a foot note, that "The Committee expects States to interpret development as a "holistic concept, embracing the child's physical, mental, spiritual, moral, psychological and social development” (General Comment No 5, para. 12)"37.

"Shall be a primary consideration". The phrase "shall be a primary consideration" is analysed in paragraphs 36 to 40 of the CRC General Comment No 14. The principal idea of this paragraph is that it gives the pattern to resolve a conflict of interests when it involves a child/children interest. As paragraph 39 establishes, “...Potential conflicts between the best interests of a child, considered individually, and those of a group of children or children in general have to be resolved on a case-by-case basis, carefully balancing the interests of all parties and finding a suitable compromise. The same must be done if the rights of other persons are in conflict with the child's best interests. If harmonization is not possible, authorities and decision-makers will have to analyse and weigh the rights of all those concerned, bearing in mind that the right of the child to have his or her best interests taken as a primary consideration means that the child's interests have high priority and not just one of several considerations. Therefore, a larger weight must be attached to what serves the child best”.

Anyway, two more ideas are important to understand the scope of the principle.

The first idea is pointed out in paragraph 40 , and it is that the best interests of the child has to be considered even before the conflict has raised, i.e. we have to take into account the principle when we have to take a decision that is going to affect a child or a group of children or children in general.

\footnotetext{
${ }^{37}$ In this line, we have to consider that the best interests of the child, with or without disabilities, is the same than the best interests of any person: to achieve the free development of his/he own personality; therefore it is necessary that he/she could enjoy, full and effectively, all his/her human rights. It can be seen a developing and justification of those ideas in (Campoy Cervera, 2017b).
} 
The second idea is established in paragraph 38, and it is that in some decisions that affect children "the right of best interests is further strengthened; it is not simply to be "a primary consideration" but "the paramount consideration". Indeed, the best interests of the child are to be the determining factor when taking a decision on adoption, but also on other issues" ${ }^{38}$. Thus, we have to understand that it is the same for all children, with or without disabilities.

\section{IV.3. Paragraph 3}

As we pointed out above, the wording of the right of the child to be heard -Art. 12 CRC- as well as the child's best interests -Art. 3.1 CRC - was not clear. It is precisely the wording of Article 12 that was even more distant from all that this general principle has represented, represents and will surely represent in relation to the construction of an adequate system of recognition and protection of rights of the children according to the human rights model ${ }^{39}$.

Anyhow, except for the last phrase of paragraph 3 and what it means the explicitly inclusion of children with disabilities, the paragraph reproduce in the essential the same wording of Art. $12.1 \mathrm{CRC}^{40}$. It is true that the wording of the article seems to recognize only that the States Parties shall ensure that children with disabilities have the right to express their views freely (and the necessity of given due weight to these views in accordance with their age and maturity) on an equal basis with other children. Nevertheless, the fact is that it is accepted that what is recognized is the right to participate in all the matters that concern them ${ }^{41}$. In this line, it will be necessary, to understand the meaning of this principle and right, to follow what the Committee on the Rights of the Child established in its General Comment No 12 and also to attend to paragraphs 32 and 33 of the CRC "General Comment No 9 on the rights of children with disabilities", which are dedicated to the principle and right of Art. 12 CRC, "Respect for the views of the child".

"States Parties shall ensure". The Committee on the Rights of the child analysed the terms "shall assure" of Art. 12.1 CRC, in paragraph 19 of the CRC General Comment No 12; and this analysis can be used to understand the meaning of "States Parties shall ensure" of Art. 7.3 CRPD. In this sense, the Committee asserts firmly that this determine a strict obligation to the States to undertake appropriate measures "to ensure that mechanisms are in place to solicit the views of the child in all matters affecting her or him and to give due weight to those views”.

\footnotetext{
${ }^{38}$ In fact, this paramount consideration is said, in paragraph 38, in respect of adoption, because Art 21 of CRC explicitly says: "the system of adoption shall ensure that the best interests of the child shall be the paramount consideration”.

${ }^{39}$ As has been indicated in the Introduction, this model means to recognize that children, with or without disabilities, have the capacity to exercise their rights not only on an equal basis with each other, but also on an equal basis with adults (Campoy Cervera, 2017b).

${ }^{40}$ Art. 7.3 CRPD establishes: "States Parties shall ensure that children with disabilities have the right to express their views freely on all matters affecting them, their views being given due weight in accordance with their age and maturity, on an equal basis with other children, and to be provided with disability and age-appropriate assistance to realize that right"; and Art. 12.1 CRC: "States Parties shall assure to the child who is capable of forming his or her own views the right to express those views freely in all matters affecting the child, the views of the child being given due weight in accordance with the age and maturity of the child".

${ }^{41}$ United Nations Committee on the Rights of the Child CRC "General Comment No 12 the right of the child to be heard” (1 July 2009) CRC/C/GC/C12 (hereafter CRC General Comment N 12), para. 3.
} 
"that children with disabilities have the right to express their views freely". In paragraphs 22 to 25 of the CRC General Comment No 12 are analysed the terms "The right to express those views freely”.

As it was said supra, the right to express their views freely has to be interpreted as the right to participate, and that means that is necessary to ensure that the participation of the child is expressing their own views, which we think that can be understood as their own will and preferences. In this line, it is highlighted that the participation (the expression of the views) has to be free and after getting the appropriate information. Thus the Committee on the Rights of the Child clarify in its General Comment No 12 that “..."Freely” means that the child can express her or his views without pressure and can choose whether or not she or he wants to exercise her or his right to be heard. "Freely" also means that the child must not be manipulated or subjected to undue influence or pressure..." of the child to express her or his views requires that the child be informed about the matters, options and possible decisions to be taken and their consequences by those who are responsible for hearing the child, and by the child's parents or guardian. The child must also be informed about the conditions under which she or he will be asked to express her or his views. This right to information is essential, because it is the precondition of the child's clarified decisions" ${ }^{\prime 3}$.

Anyway, it is important to highlight that for the effective exercise of this right all the conditions that ensure that the child can participate freely has to be adapted to the conditions of the child, without or with disabilities. In this sense it is very interesting the paragraph 23 of the General Comment No 12: "States parties must ensure conditions for expressing views that account for the child's individual and social situation and an environment in which the child feels respected and secure when freely expressing her or his opinions". Which is necessary for all the children, but even more for the children with disabilities, due to the special barriers that they have to face in our societies.

“on all matters affecting them”.

In paragraphs 26 and 27 of the CRC General Comment No 12 are analysed the terms "In all matters affecting the child". In these paragraphs it is said that "... While the Committee supports a broad definition of "matters", which also covers issues not explicitly mentioned in the Convention, it recognizes the clause "affecting the child", which was added in order to make clear that no general political mandate was intended...”. Anyway, it is clear that the concept have to be understood in a very broad sense, to all matters that directly or indirectly affect children with disabilities as a group or in general, as well as if they have an effect on an individual child with any type of disability. That it is to say that here we have to reproduce what has been said supra in the analysed of the terms "In all actions concerning children with disabilities" in relation with the best interests of the child. With this extensive interpretation of the child's participation, without or with disability, it would be understood, on the one hand, that the child with disability must be able to participate in decision-making on all matters that affect him/her, directly or indirectly, in his/her personal, family, legal, political, economic, social or cultural life; and on the other hand, that children with

\footnotetext{
42 Ibid, para. 22.

${ }^{43}$ Ibid, para. 25. Paragaphs 37 and 38 of the CRC General Comment No 9 are also dedicated to their right to "Access to appropriate information and mass media”.
} 
disabilities can be affected for all these matters individually and collectively, as groups of children and as children in general ${ }^{44}$.

In this line, it is interesting the recall of the Committee on the Rights of the Child on the damage that for children with disabilities have the practice of reducing their participation in the matters that affect them as children with disabilities: “...Their participation in events and activities catering to these essential aspects of any child's life is either totally lacking or minimal. Furthermore, when their participation is invited, it is often limited to activities specifically designed for and targeted at children with disabilities. This practice only leads to further marginalization of children with disabilities and increases their feelings of isolation..." ${ }^{45}$.

Anyway, an enormous mistake is to misunderstanding what are the matters that affect the children with disabilities. In this sense, it is necessary to understand that they are affected for the same matters than the other children, because first of all they are children.

"their views being given due weight in accordance with their age and maturity on an equal basis with other children".

In paragraphs 28 to 31 of the CRC General Comment No 12 are analysed the terms "Being given due weight in accordance with the age and maturity of the child".

There are two main questions in relation with the meaning of the phrase that we analyse here and one very important consequence for the exercise of the rights of children with disabilities.

The first question is: what does it mean "being given due weight"? The answer of the Committee on the Rights of the Child is clear, the views, thus his/her will and preferences, have to be seriously considered to take the corresponding action, and then child (or children) has to be communicated about the way in which his/her views have influenced the outcome of the process ${ }^{46}$, and if they were rejected why were them.

The second question is: when can we understand that the child has the capacity to express his/her views in order to consider them for the decision-making process? According with the Committee, on the one hand, the "age alone cannot determine the significance of a child's views", therefore, "the views of the child have to be assessed on a case-by-case examination" "47; and on the other hand, "Maturity refers to the ability to understand and assess the implications of a particular matter, and must therefore be considered when determining the individual capacity of a child. Maturity is difficult to define; in the context of article 12, it is the capacity of a child to express her or his views on issues in a reasonable and independent manner" ${ }^{\text {" }}$.

Anyway, the best understanding, according with the human rights model, is that every child has the right to participate, it does not matter his/her age or maturity. The

\footnotetext{
${ }^{44}$ Vid. CRC General Comment No 12, para. 87.

${ }^{45}$ CRC General Comment No 9, para. 33.

${ }^{46}$ Vid. CRC General Comment No 12, para. 28.

${ }^{47}$ Ibid, par. 29.

${ }^{48}$ Ibid, para. 30.
} 
age and maturity are important only to determine the due weight that has been given to the will and preferences of the child ${ }^{49}$.

Thus, the very important consequence for the exercise of the rights of children with disabilities, is that in the exercise of this important right (that is the right to participate in all matters affecting them), the only two criteria that can be taken in account to assess the given due weight to the views of the child are his/her age and his/her maturity. So it can never be the disability, any type of disability. It is important to stress the essentiality that the children with disabilities participate on all matters affecting them, being given due weight to their wills and preferences in accordance with their age and maturity. Here the end of the analysed sentence, "on an equal basis with other children", has all the importance, because it determines explicitly the application of the social model of disability for the rights of children with disabilities. Of course, this phrase is in the wording of the principle-right to participate in all the matters that affect to children with disabilities, but on one hand, as we explained supra, this is one of the four main principles of the whole Convention on the Rights of the Child, and on the other hand this is one of the two (with the bests interests of the child) principles-rights that are highlighted in the only article that the Convention of the Rights of Persons with Disabilities dedicates to children with disabilities. Thus, and according with the analysis done supra in relation with paragraph 1 of Art. 7, we have to conclude that the States have to ensure that children with disabilities can exercise this right to participate, as any other right, on equal basis with other children ${ }^{50}$.

In the same line, the World Blind Union, in the Daily summary of discussion at the sixth session, 2 August 2005, explained: "the importance of allowing children with disabilities to develop their own skills and potential by allowing them to make their own mistakes. Everyone learns from making mistakes and finds their limitations. Often, children with disabilities are over protected not just by their parents but also by society. This denies children with disabilities the right to speak for themselves. Parents and teachers are not educated to give children with disabilities the opportunities to make these mistakes, to correct themselves and to make decisions. The only way to change

\footnotetext{
${ }^{49}$ In this sense, it was an unfortunate expression of the Committee when it said: "the views of the child have to be seriously considered when the child is capable of forming her or his own views". As it is better said in the United Nations Committee on the Rights of the Child, "General Comment No 7 Implementing child rights in early childhood” (20 September 2006) CRC/C/GC/7/Rev.1, (hereafter CRC General Comment No 7), para 14, "The Committee wishes to emphasize that article 12 applies both to younger and to older children. As holders of rights, even the youngest children are entitled to express their views, which should be "given due weight in accordance with the age and maturity of the child" (art. 12.1)". Furthermore, in the CRC General Comment No 12 it is also said: "The impact of the matter on the child must also be taken into consideration. The greater the impact of the outcome on the life of the child, the more relevant the appropriate assessment of the maturity of that child” (para. 30).

50 The importance of participation for children with disabilities was highlighted by the Committee on the Rights of the Child: "It is essential that children with disabilities be heard in all procedures affecting them and that their views be respected in accordance with their evolving capacities. In order for this principle to be respected, children should be represented in various bodies such as parliament, committees and other forums where they may voice views and participate in the making of decisions that affect them as children in general and as children with disabilities specifically. Engaging children in such a process not only ensures that the policies are targeted to their needs and desires, but also functions as a valuable tool for inclusion since it ensures that the decision-making process is a participatory one. Children should be provided with whatever mode of communication they need to facilitate expressing their views. Furthermore, States parties should support the training for families and professionals on promoting and respecting the evolving capacities of children to take increasing responsibilities for decision-making in their own lives” (CRC General Comment No 9, para. 32).
} 
attitudes towards children with disabilities is to recognize their own capacity. Their selfdetermination should be honoured in accordance with age and maturity. Disabled children must be allowed to make their own lives through their own experiences. This can only be achieved through a strong reference to disabled children that does not regard them as a homogenous group" ${ }^{\text {1. }}$.

"to be provided with disability and age-appropriate assistance to realize that right”.

This phrase clearly set out what is necessary to ensure that the children with disabilities can exercise their right to participate (in fact, all their rights): receive the appropriate assistance to realize the right. It is referred to age-appropriate assistance as well, and this has sense, because as the Committee on the Rights of the Child points out: "Respect for the young child's agency - as a participant in family, community and society - is frequently overlooked, or rejected as inappropriate on the grounds of age and immaturity" ${ }^{52}$. Thus, it is important to reverse that situation and give the support for the children of all ages and of any type of disability in order to exercise their right to participate in accordance with their evolving capacities ${ }^{53}$.

Finally, as it was explained supra in relation with Art 7.1, the key to fulfil the obligation that children with disabilities can exercise all their rights on an equal basis with other children, is the need to remove existing barriers and ensure universal accessibility for children with disabilities. Thus it has to be applied the universal design and the accessible measures, given the necessary support and, where appropriate, the reasonable adjustments for the exercise of their rights. It is in that line that we have to understand the obligation to provide the appropriate assistance to make their rights real. Anyway, the use of the term "assistance" allows to incorporate the necessity of providing the important figure of the personal assistant; his/her activity can be necessary to the exercise of very different rights and freedoms in order to ensure that children with disabilities can exercise them on equal basis with others.

\section{THE INTER-RELATIONSHIP BETWEEN ARTICLE 7 AND OTHER CRPD}

\section{ARTICLES}

From what we have already analysed, Article 7 CRPD establishes the principles to set out that all the children, with or without disabilities, have the same human rights and fundamental freedoms, and the States have the obligation to adopt all the measures that will be necessary to ensure that children with disabilities can effectively fully enjoy them on equal basis with other children. Thus, we can understand that all the articles of the CRPD are related with Article 7 in some way, because all of them are related with children with disabilities ${ }^{54}$. Furthermore, in the CRPD Preamble it is said that

\footnotetext{
51 UN Convention on the Human Rights of People with Disabilities. Ad Hoc Committee - Daily Summaries. Daily summary of discussion at the sixth session. Volume 7, \#2, August 02, 2005, http://www.un.org/esa/socdev/enable/rights/ahc6sum2aug.htm.

52 CRC General Comment No 7, para. 14.

${ }^{53}$ In this line, in relation with the necessity to apply Article 12 CRC to younger children, the Committee on the Rights of the Children, asserted: “...young children are holders of all the rights enshrined in the Convention. They are entitled to special protection measures and, in accordance with their evolving capacities, the progressive exercise of their rights...” (CRC General Comment No 7, para. 3).

${ }^{54}$ In this line, and in relation with the right to participate of Article 7.3, although we can point out some rights that are more closely linked to the exercise of the right to participate, as the freedom of expression
} 
"Recognizing that children with disabilities should have full enjoyment of all human rights and fundamental freedoms on an equal basis with other children, and recalling obligations to that end undertaken by States Parties to the Convention on the Rights of the Child". And in the Convention on the Rights of the Child we can find human rights of all the generations: individual, civil, political, economic, social and cultural rights, that we can find in different Articles of CRPD as well. Moreover, it is important to recall that the Committee on the Rights of the Child affirmed, in paragraph 4 of its General Comment No 14, that "The concept of the child's best interests is aimed at ensuring both the full and effective enjoyment of all the rights recognized in the Convention and the holistic development of the child”.

Anyhow, it is also clear that there are some articles of the CRPD that are specially related with Article 7, because the content of them have special importance for children's rights. Some of them attend to general principles that, in accordance with have been explained before, are necessary for the appropriate exercise of the rights of children with disabilities, for example the right to equality and non-discrimination of Article 5 or the right to accessibility of Article 9.

On the other hand, other Articles regulate matters affecting directly to children with disabilities, although in its wording there is not mention to them, for example the access to justice of Article 13, the freedom from exploitation, violence and abuse of Article 16, or the freedom of expression and opinion, and access to information of Article 21.

Anyhow, there are other Articles of the Convention in which there are explicit mentions to children. Those could be separate in three groups, those who attend to children rights in a global way, those who attend to rights that have special meaning to children with disabilities and those who stress the necessity to adopt appropriate measures to ensure specific rights to children with disabilities. Thus, we can located among the first ones Articles 3, 4 and 6; among the second category Articles 18, 23 and 24; and among the later Articles 8, 25, 28 and 30.

Thus, Article $3 \mathrm{~h}$ ) establishes as one of the principles of the Convention "Respect for the evolving capacities of children with disabilities and respect for the right of children with disabilities to preserve their identities". Article 4.3, fixes, as one of the general obligations of the States Parties, that "In the development and implementation of legislation and policies to implement the present Convention, and in other decision-making processes concerning issues relating to persons with disabilities, States Parties shall closely consult with and actively involve persons with disabilities, including children with disabilities, through their representative organizations". Moreover, in Article 6, in spite of its title "Women with disabilities", is taken into account the multiple discrimination suffered by women and girls with disabilities.

and opinion, and access to information of Article 21 (as the Committee on the Rights of the Child affirms, in relation with the Articles of the CRC: "Article 13, on the right to freedom of expression, and article 17, on access to information, are crucial prerequisites for the effective exercise of the right to be heard". (CRC General Comment No 12, para. 80); we can also point out the general connection of this Article 7.3 with all the rights of children with disabilities, because, as it has been said in the previous section, we have to understand that precisely this right is recognized to children with disabilities to participate on all matters affecting them, i.e. to all the matters that are regulated in CRPD. 
On the other hand, Article 18.2 recognizes that "Children with disabilities shall be registered immediately after birth and shall have the right from birth to a name, the right to acquire a nationality and, as far as possible, the right to know and be cared for by their parents". Article 23.1.c) establishes the obligation of the Sates Parties to ensure that children with disabilities "retain their fertility on an equal basis with others"; and in the points 2, 3, 4 and 5 establishes several measures that the States Parties have to take in order to eliminate any discrimination against children with disabilities in all matters relating to parenthood, family life and relationships between its members, enjoying their rights on an equal basis with others. And Article 24 recognizes the right to inclusive education $^{55}$, which is the right of all children, with or without disabilities, to be educated in the same inclusive general education system without discrimination and on the basis of equal opportunities.

Finally, Article 8.2.b) establishes as one of the measures that States Parties have to adopt immediately, in an effective and appropriate way to raise awareness throughout society, "Fostering at all levels of the education system, including in all children from an early age, an attitude of respect for the rights of persons with disabilities". Article 25 b) fixes that the States, in relation with the right to health, "Provide those health services needed by persons with disabilities specifically because of their disabilities, including early identification and intervention as appropriate, and services designed to minimize and prevent further disabilities, including among children and older persons". Article 28.2.b) points out that in order to safeguard and promote the realization of the right to social protection, the States Parties shall particularly ensure access by girls with disabilities "to social protection programmes and poverty reduction programmes". And Article 30.5.d) establishes that States Parties shall take appropriate measures "To ensure that children with disabilities have equal access with other children to participation in play, recreation and leisure and sporting activities, including those activities in the school system”.

\section{THE INTERPRETATION OF ARTICLE 7 IN THE EUROPEAN COURT OF HUMAN RighTS}

In Europe, although the two principles of Article 7 are decisive in the construction of the system of the children's rights, the references in the regional courts has been clearly much larger to the principle of the best interests of the child than to the principle of participation on all matters affecting them, most probably due to the fact of the prevalence of the "renew" protectionism model. Anyway, the references to them, even when it has been involved a right of children with disabilities, use to be in relation with Article 3.1 of CRC rather than to Article 7 CRPD.

Nevertheless, there is an important exception in the case of Guberina v. Croatia, [2016], where, among other Articles of CRPD, is explicitly referred Article 7 (although it is omitted its third paragraph) ${ }^{56}$, whereas it is not CRC. "This case concerned the complaint by the father of a severely handicapped child about the tax authorities' failure to take account of the needs of his child when determining his eligibility for tax

\footnotetext{
${ }^{55}$ Vid United Nations Committee on the Rights of Persons with Disabilities, "General Comment No. 4 Article 24: Right to inclusive education” (2 September 2016), CRPD/C/GC/4.

${ }^{56}$ Guberina v. Croatia, [2016], par. 34.
} 
exemption on the purchase of property adapted to his child's needs" 57 . The case was decided by the Court on Article 14 of the European Convention on Human Rights, taken in conjunction with Article 1 of Protocol No 1. The Court "finds that the alleged discriminatory treatment of the applicant on account of the disability of his child, with whom he has close personal links and for whom he provides care, is a form of disability-based discrimination covered by Article 14 of the Convention"58. However, although it can be seen a reference to Article 7.2 in paragraph 73 of the Judgment, the specific content of Article 7 CRPD had not an important role in it.

Anyhow, perhaps the most interesting cases are those where it was involved a right of a child with disabilities and the European Court has referred to the CRPD to protect this right and it has been claimed as well the principle of the best interests of the Child, although it has not been referred to Article 7 CRPD.

It is the case of R.P. and others v. the United Kingdom [2012] and Kacper Nowakowski v. Poland [2017].

In R.P. and others v. the United Kingdom [2012] the European Court decided on the legitimation of the appointment of Official Solicitor to represent a mother with learning disabilities in a child care proceeding, in relation to the ability of the mother to provide the necessary care to her child, who was a premature baby and had a number of serious medical conditions requiring constant care. The Court decided the case on Article 6.1 of the European Convention on Human Rights, right to a fair trial in civil proceedings. However, the Court referred to the Convention on the Rights of Persons with Disabilities, in particular Articles 1, 5, 12, 13 and $23^{59}$. Although it was not named Article 7, Article 23, as we said above, is directly linked with Article 7. In this case, the link is because Article 23.2 and 4 establishes that the best interests of the child shall be of the most importance in order to decide with regard to guardianship, wardship, trusteeship, adoption of children or similar institutions; and also that the separation of the child from his or her parents against their will can only be done if it is necessary for the best interests of the child. Thus, although in this case were directly involved other Articles of the Convention, it is important to note that the paramount importance of the child bests interests does that this principle always has a decisive influence when the decision affects a child. In this line, the European Court asserted “...However, the Court accepts that the best interests of K.P. [K.P. was the child who was born prematurely] were the touchstone by which the domestic courts would assess the case. Thus, in determining whether a case was arguable or not, it was necessary for the Official Solicitor to consider what was in K.P.'s best interests...”60.

In Kacper Nowakowski v. Poland [2017] the European Court decided on maintaining the contacts of a deaf and mute father with his son, who also had a hearing impairment. The Court decided the case on Article 8 of the European Convention on Human Rights, right to respect for private and family life. However, the Court referred to the Convention on the Rights of Persons with Disabilities, in particular Articles 5 and

\footnotetext{
${ }^{57}$ European Court of Human Rights, Press Unit, Factsheet - Persons with disabilities and the European Convention on Human Rights, March 2017, p. 24.

${ }^{58}$ Guberina v. Croatia, [2016], par. 79.

${ }^{59}$ R.P. and others v. the United Kingdom [2012], para 43.

${ }^{60}$ R.P. and others v. the United Kingdom [2012], para 75.
} 
$23^{61}$. In this case, the direct link is with Article 23.2 when it says: "States Parties shall render appropriate assistance to persons with disabilities in the performance of their child-rearing responsibilities”62. Anyway, what is more important here is to observe that, in spite of in the Judgment it is not referred Article 7 CRPD, the Court explicitly invoked the decisive importance of the principle of the best interests of the child, although through Articles 3.1 and 9 CRC (and even though the best interests is also referred in Article 23 CRPD) ${ }^{63}$.

On the other hand, it is also interesting to note that in other cases where a right of a child with disabilities has been affected, the European Court has taken the best interests of the child as a principle of primary consideration as well, although it was no reference to Article 7 CRPD. In this line, in Blokhin v. Russia [2016] ${ }^{64}$, although the Mental Disability Advocacy Center referred (among the third party observations) to the Convention on the Rights of the Persons with Disabilities ${ }^{65}$ and "reiterated that the best interests of the child had to be of primary importance" 66 , the Article referred by the European Court in relation with this principle was Article 3 CRC and not Article 7.2 CRPD $^{67}$.

Furthermore, the principle of the best interests of the child has been taken into account in other cases where the children's rights where affected although it has not been referred neither the CRC nor the CRPD as, for example, A.M.M. v. Romania $[2012]^{68}$.

The last consideration that have to be pointed out is that there are cases related with the rights of children with disabilities in which have not referred neither of the two principles (nor the best interests of child nor the participation on all matters that affect

\footnotetext{
${ }^{61}$ Kacper Nowakowski v. Poland [2017], par. 49.

${ }^{62}$ Kacper Nowakowski v. Poland [2017], par. 93.

${ }^{63}$ Kacper Nowakowski v. Poland [2017], pars. 50 and 81. In this line, it is interesting the recall of the Court in paragraph 75: "The Court recalls that there is currently a broad consensus including in international law - in support of the idea that in all decisions concerning children, their best interests must be paramount (see Neulinger and Shuruk [GC], no. 41615/07, § 135, 6 July 2010, and X v. Latvia [GC], no. 27853/09, § 96, ECHR 2013). The child's best interests may, depending on their nature and seriousness, override those of the parents (see Sahin, cited above, § 66). The parents' interests, especially in having regular contact with their child, nevertheless remain a factor when balancing the various interests at stake (see Neulinger and Shuruk, cited above, § 134). Child interests dictate that the child's ties with its family must be maintained, except in cases where the family has proved particularly unfit. It follows that family ties may only be severed in very exceptional circumstances and that everything must be done to preserve personal relations and, if and when appropriate, to "rebuild" the family (see Gnahoré v. France, no. 40031/98, § 59, ECHR 2000 IX)”.

${ }^{64}$ European Court of Human Rights, Press Unit, Factsheet - Persons with disabilities and the European Convention on Human Rights, March 2017, 13. This case "concerned the detention for 30 days of a 12year old boy, who was suffering from a mental and neurobehavioural disorder, in a temporary detention centre for juvenile offenders”.

65 Blokhin v. Russia [2016], para 134.

${ }^{66}$ Blokhin v. Russia [2016], para 191.

${ }^{67}$ Blokhin v. Russia [2016], paras 81 and 134.

68 "The case concerned paternity proceedings brought by the mother of a minor with disabilities, who was herself severely disabled. The domestic courts did not strike a fair balance between the child's right to have his interests safeguarded in the proceedings and the right of his putative father not to undergo a paternity test or take part in the proceedings” (European Court of Human Rights, Press Released, issued by the Registrar of the Court, ECHR 057 (2012), Romanian courts did not respect the right to respect for private and family life in paternity proceedings concerning a minor, February 2012, 1).
} 
them), even when the Convention on the Rights of Persons with disabilities has been referred, as, for example, the case of Đorđević v. Croatia [2012] ${ }^{69}$,

Finally, it is worthy to notice than, as it has been pointed out supra, we can hardly have any references to the principle of participation of children on all matters that affect them in cases where the right of a child with disabilities was involved, and in any case without reference to Article 7 of $\mathrm{CRPD}^{70}$. Nevertheless, the Committee on the Rights of Persons with Disabilities has repeatedly highlighted the decisive importance of the principle and right to participate. In fact, in its comments to the reports of the States Parties to the CRPD, it had emphasized its concern "that children with disabilities are not able to systematically participate in decision-making that affects their lives and that they do not have the opportunity to express their opinion on matters pertaining to them directly"; and so urges the States Parties "to adopt safeguards to protect the right of boys and girls with disabilities to be consulted on all matters that affect them, and to guarantee them effective assistance to realize that right, bearing in mind their disability and age" ${ }^{, 71}$.

\section{CONCLUDING REMARKS}

Article 7 CRPD implies the application of the principles that support the current paradigm of children's rights, promoted by the CRC, to children with disabilities, as required by the social model of disability.

In this sense, there is an interconnection between Article 7.1 CRPD and Article 2 CRC, and the recognition of the general principle and right to non-discrimination, and specifically the prohibition of discrimination on the ground of disability, to ensure that the children with disabilities can enjoy their human rights on equal basis with other children; between Article 7.2 CRPD and Article 3.1 CRC, and the recognition of the general principle and right of the best interests of the child as a primary consideration; and between Article 7.3 and Article 12.1 CRC, and the recognition of the general principle and right of the children to be heard on all matters affecting them.

\footnotetext{
69 "This case concerned the complaint by a mother and her mentally and physically disabled son that they had been harassed, both physically and verbally, for over four years by children living in their neighbourhood, and that the authorities had failed to protect them" (European Court of Human Rights, Press Unit, Factsheet - Persons with disabilities and the European Convention on Human Rights, March 2017, 9).

${ }^{70}$ The only case that we have found where is a slight reference to the right of the child to be heard (without reference to the CRPD) was of Saviny v. Ukraine [2008], para. 59. And as Broderick notes: "The jurisprudence of the ECtHR on the issue of children's participation in decision-making processes is not particularly instructive - the case law of the Court in this area has been slow to develop, and the Court has traditionally taken a paternalistic viewpoint on the issue of children's evolving autonomy” (Broderick, 2017, 209).

${ }^{71}$ United Nations Committee on the Rights of Persons with Disabilities, Concluding observations on the initial report of the Czech Republic (2015), CRPD/C/CZE/CO/1, paras. 15-16. It can be seen in the same line in Concluding observations on the initial report of Belgium (2014), CRPD/C/BEL/CO/1, paras. 1516; Concluding observations on the initial report of Croatia (2015), CRPD/C/HRV/CO/1, paras. 11-12; Concluding observations on the initial report of Germany (2015), CRPD/C/DEU/CO/1, paras. 17a)-18a); Concluding observations of the Committee on the Rights of Persons with Disabilities Spain (2011), $\mathrm{CRPD} / \mathrm{C} / \mathrm{ESP} / \mathrm{CO} / 1$, paras. 23-24 b); and Concluding observations on the initial report of Sweden (2014), CRPD/C/SWE/CO/1, paras. 19-20.
} 
As it has been explained on the section of Background and Travaux Préparatoires, there had been a debate, in the Ad Hoc Committee on a Comprehensive and Integral International Convention on the Protection and Promotion of the Rights and Dignity of Persons with Disabilities, between those who considered appropriate to include a specific Article on children with disabilities and those who consider better to include a general provision on children with disabilities on the general principles and obligations CRPD and address the specific circumstances of children with disabilities in the regulation of particular rights. Finally, the CRPD has the Article 7 on children with disabilities and there are other Articles in the CRPD that also regulate basic rights of children with disabilities, as, for example, the right to education on Article 24.

Anyhow, both principles-rights have different grounds. The best interests has older roots and is grounded on the protection of the children, and the participation of children on all the matters that affect them was driven from the CRC and is grounded on the recognition of their autonomy and evolving capacities to exercise their rights. Up to date, the jurisprudence of the European Court of Human Rights had been almost only focused on the best interests of the child principle; although the Committee on the Rights of Persons with Disabilities has repeatedly highlighted the decisive importance of the principle and right of the children to participate in the decisions-making on all matters that affect them.

\section{REFERENCES}

Alston, P. and Gilmour-Walsh, B. (1996). The Best Interests of the Child: Towards a synthesis of children's rights and cultural values. Florence: UNICEF International Child Development Centre.

Broderick, A. (2017). Article 7 [Children with Disabilities]. In: V. Della Fina, R. Cera and G. Palmisano, ed., The United Nations Convention on the Rights of Persons with Disabilities. Switzerland: Springer International Publishing.

Campoy Cervera, I. (2017a). Ideas for the construction of a human rights model for children, with or without disabilities. In: C. O’Mahony and G. Quinn, ed., Disability Law and Policy. An Analysis of the UN Convention. Ireland: Clarus Press, pp. 17-31.

Campoy Cervera, I. (2017b). La construcción de un modelo de derechos humanos para los niños, con o sin discapacidad. Derechos y Libertades, (37), pp.131-165.

Campoy Cervera, I. (2016). Los niños y las niñas con discapacidad ante la modificación legislativa del sistema de protección a la infancia y a la adolescencia. In: C. Martínez García, ed., Tratado del Menor. La protección jurídica a la infancia y la adolescencia. Navarra: Aranzadi, pp.743-765.

Campoy Cervera, I. (2006). La fundamentación de los derechos de los niños. Modelos de reconocimiento y protección. Madrid: Dykinson.

Cardona Llorens, J. (2014). El interés superior del niño: balance y perspectivas del concepto en el $25^{\circ}$ aniversario de la Convención sobre los Derechos del Niño. Revista española de desarrollo y cooperación, ( ${ }^{\circ}$ extraordinario, otoño de 2014). 
De Asís Roig, R. (2013). Sobre discapacidad y derechos. Madrid: Dykinson.

Detrick, S., ed., (1992). The United Nations Convention on the Rights of the Child. A Guide to the "Travaux Préparatoires", The Netherlands: Martinus Nijhoff Publishers.

European Court of Human Rights, Press Released, issued by the Registrar of the Court, ECHR 057 (2012), Romanian courts did not respect the right to respect for private and family life in paternity proceedings concerning a minor, February 2012.

European Court of Human Rights, Press Unit, Factsheet - Persons with disabilities and the European Convention on Human Rights, March 2017, available at: http://www.echr.coe.int/Documents/FS_Disabled_ENG.pdf.

Un.org. (2017). UN Enable - Promoting the rights of Persons with Disabilities - Ad Hoc Committee. [online] available at:

http://www.un.org/esa/socdev/enable/rights/adhoccom.htm.

\section{UnITED NATIONS COMMITTEES DOCUMENTS}

United Nations Committee on the Rights of the Child, "General Comment No 7 Implementing child rights in early childhood” (20 September 2006) CRC/C/GC/7/Rev.1.

United Nations Committee on the Rights of the Child "General Comment No 9 on the rights of children with disabilities” (27 February 2007) CRC/C/GC/9.

United Nations Committee on the Rights of the Child CRC "General Comment No 12 the right of the child to be heard” (1 July 2009) CRC/C/GC/C12.

United Nations Committee on the Rights of the Child "General Comment No 14 on the right of the child to have his or her best interests taken as a primary consideration (art. 3, para. 1)” (29 May 2013) CRC/C/GC/14

United Nations Committee on the Rights of Persons with Disabilities "General Comment No 2 Article 9: Acccesibility” (22 May 2014) CRPD/C/GC/2.

United Nations Committee on the Rights of Persons with Disabilities "General Comment No 3 on women and girls with disabilities" (25 November 2016) $\mathrm{CRPD} / \mathrm{C} / \mathrm{GC} / 3$.

United Nations Committee on the Rights of Persons with Disabilities, "General Comment No. 4 Article 24: Right to inclusive education” (2 September 2016), $\mathrm{CRPD} / \mathrm{C} / \mathrm{GC} / 4$.

United Nations Committee on the Rights of Persons with Disabilities, Concluding observations on the initial report of the Czech Republic (2015), CRPD/C/CZE/CO/1.

United Nations Committee on the Rights of Persons with Disabilities, Concluding observations on the initial report of Belgium (2014), CRPD/C/BEL/CO/1.

United Nations Committee on the Rights of Persons with Disabilities, Concluding observations on the initial report of Croatia (2015), CRPD/C/HRV/CO/1. 
United Nations Committee on the Rights of Persons with Disabilities, Concluding observations on the initial report of Germany (2015), CRPD/C/DEU/CO/1.

United Nations Committee on the Rights of Persons with Disabilities, Concluding observations of the Committee on the Rights of Persons with Disabilities Spain (2011), CRPD/C/ESP/CO/1.

United Nations Committee on the Rights of Persons with Disabilities, Concluding observations on the initial report of Sweden (2014), CRPD/C/SWE/CO/1.

\section{COURT CASES AT THE European Court OF Human Rights}

A.M.M. v. Romania [2012] App no 2151/10, 14 February 2012 (European Court of Human Rights).

Blokhin v. Russia [2016] App no 47152/06, 23 March 2016 (European Court of Human Rights).

Đorđević v. Croatia [2012] App no. 41526/10, 24 July 2012 (European Court of Human Rights).

Guberina v. Croatia [2016] App no 23682/13, 22 March 2016 (European Court of Human Rights).

Kacper Nowakowski v. Poland [2017] App no 32407/13, 10 January 2017 (European Court of Human Rights).

R.P. and others v. the United Kingdom [2012] App no 38245/08, 9 October 2012 (European Court of Human Rights).

Saviny v. Ukraine [2008] App no. 39948/06, 18 December 2008 (European Court of Human Rights). 